\title{
Is Psychology a Health Profession? An Opinion of a Sample of Psychologists Worldwide
}

¿Es la Psicología una profesión sanitaria? La opinión de una muestra mundial de psicólogos

Recibido: agosto 31 de 2011 | Revisado: febrero 2 de 2012 | Aceptado: febrero 26 de 2012

\author{
IZABELA ZYCH* \\ Universidad de Córdoba, España \\ Gualberto BuEla-CASAL ** \\ MARÍA PAZ BERMÚdEZ *** \\ JUAN CARLOS SIERRA**** \\ Universidad de Granada, España
}

A B S T R A C T

The purpose of the current study is to evaluate the opinions of the scientific community of psychologists on the question if psychology is a health profession. Nowadays, the subject is even more important as there are laws, as for example the Ley de Ordenación de Profesiones Sanitarias (LOPS) [Law for the Organization of the Health Professions] in Spain that should be based on the concept that psychology is or is not a health profession. Moreover, the creation of the common curricula for the whole Europe needs the general agreement and no individual opinion can be valid for these purposes. The present study shows the opinion of 803 scientists who have published at least one article in a clinical or multidisciplinary psychology journal included in the Web of Science, from 42 different countries, 23 major fields of psychology and 32 orientations. The results show that, in general, the participants answered that psychology is a health profession, which is even more evident in case of clinical psychology.

Key words authors

Image of psychology, health profession, psychology, study of population by means of a survey, health.

Key words plus

Clinical Psychology, Psychology as a Discipline

Para citar este artículo: Zych, I., Buela-Casal, G., Bermúdez, M. P. \& Sierra, J. C. (2013). Is psychology a health profession? An opinion of a sample of psychologists worldwide. Universitas Psychologica, 12(1), 157-171.

* Licenciada y Doctora en Psicología, Universidad de Granada. Profesora Departamento de Psicología, Facultad de Ciencias de la Educación. Avda. San Alberto Magno s/n, 14004 Córdoba (España). Email: izych@uco.es

* Catedrático de Psicología. Presidente de la Asociación Española de Psicología Conductual. E-mail: gbuela@ugr.es

**** Licenciada y Doctora en Psicología. Profesora Titular de grado y postgrado. E-mail: maripaz@ugr. es

\section{RESUMEN}

El objetivo del presente estudio consistió en evaluar la opinión de la comunidad científica de psicólogos sobre si la psicología es una profesión sanitaria. Hoy en día, esta cuestión es incluso más importante dado que existen leyes, como por ejemplo, la Ley de Ordenación de Profesiones Sanitarias (LOPS) en España que deberían basarse en que la psicología sea, o no, considerada sanitaria. Es más, la creación de un curriculum común a nivel europeo requiere de un acuerdo general y ninguna opinión individual puede considerarse válida. El presente estudio muestra la opinión de 803 científicos quienes han publicado al menos un artículo en una revista de psicología clínica o multidisciplinar en una revista incluida en la Web of Science, procedentes de 42 países diferentes, 23 campos de la psicología y 32 orientaciones. Los resultados muestran que, en general, los participantes contestaron que la psicología sí es una profesión sanitaria, lo cual es incluso más evidente en el caso de la psicología clínica.

\section{Palabras clave autores}

****** Doctor en Psicología. Profesor Titular en la Facultad de Psicología. Director del International Journal of Clinical and Health Psychology. E-mail: jcsierra@ugr.es

La imagen de la psicología, profesión sanitaria, psicología, estudio de población mediante encuesta, salud.

Palabras clave descriptores:

Psicología Clínica, Disciplina psicológica 
It is commonly known that psychology, as a science, emerged from philosophy and for many years has been a part of it. Nevertheless, there are many reasons to consider that it has also emerged from medicine. In many countries, the department of psychology was a part of the faculty of philosophy. Nevertheless, many of the most important pioneers of psychology were physicians, for example one of its fathers, W. Wundt (Buela-Casal, 2004). On the other hand, it should also be emphasized that it is still classified as social science, as can be seen on the example of the Web of Science, probably the most important database in the world, where psychology journals are included within the social science category, together with, for example, anthropology, ethics, history, law, etc. Most of the medical journals, on the other hand, are included in the science category. It can be understood that according to this database there is a substantial difference between the two.

Although it may seem that psychology is a health profession, in Spain, for example, the graduates of five to six years university studies in medicine, pharmacy, dentistry, veterinary and the graduates of three years university studies in nursery, physiotherapy, occupational therapy, podiatry, optometry, speech-language pathology and nutrition are considered health professionals according to the Spanish law. On the contrary, psychologists, together with chemists and biologists, are only considered as health professionals after an additional training program accredited by the Ministry of Health. This program lasts for four years and is available only for clinical psychology and only admits about 100 fellows a year in the whole country. This means that only about 100 psychologists a year, among 45,000 psychology students, are considered health professionals in Spain (Santolaya, 2010).

On the other hand, the Health Professions Council in the United Kingdom considers psychology as a Health Profession including its seven different areas: clinical, counseling, educational, forensic, health, occupational and sport and exercise (Health Professions Council, 2010). Postgraduate training is needed to register with the Health Professions Council.
If the Health System Profiles of the World Health Organization (2010) of 56 countries are analyzed, we find that the word "psychologist" appears 149 times throughout all the profiles, whereas the words "physician" and "nurse" appear 4,569 and 2,294 times, respectively. Thus, it can be seen that the importance given to psychology is very scarce in comparison to other fields. At the same time, there are important differences between the European countries in relation to the subject.

For these reasons, it is crucial to establish whether psychology is a health profession. Thus, the whole field could be changed and unified among different countries. Also the governments would have the opportunity to classify the science according to consensual criteria as health profession or nonhealth profession. This would clarify the current confusion and if psychology is considered a health profession, finally, there would be a good reason to claim for more positions within the public healthcare system and importance in medical settings.

The psychologists who work in the field know well their work and are considered the best source of information to clarify this issue. Although it would be interesting to ask the psychology students or the general population about their vision of the profession, their knowledge on the subject is not as good as in case of the psychologists and, therefore, the latter are considered the experts who can decide best in which field it should be classified.

Taking into account the importance of the present subject, it seems surprising that there are very few papers which deal with the inclusion of Psychology in the health profession category. Some works focus on the fact that the behavioral factors play an important role in the general health. As described by VandenBos, DeLeon and Belar (1991), seven of the top ten health risk factors in the United States are related to the behavior. For this reason, the psychologists, as the behavior specialists, are a crucial part of the medical staff. Others emphasize that many medical disorders have psychological correlates (Joseph, Gierlach, Housley \& Beutler, 2005) and that there are many efficient psychological interventions that help to improve health. 
Additionally, the perception of psychology by the general population seems to point out that it is seen as a health profession. As shown by Dempsey (2007) in his study in Australia, the public tends to confuse clinical psychology and psychiatry that, according to the author, is in detrimental to the former. Nevertheless, it could be also concluded that this confusion is an evidence for the similarity of the two professions, which means that clinical psychology is recognized as a health profession. Other studies, conducted in different countries, measured a more general image of psychology in public, as for example Sans de Uhlandt, Rovella and Barbenza (1997) in Argentina; Hartwig and Delin (2003) in Australia; Friedlmayer and Russler (1995) in Austria; Montin (1995) in Finland; Raviv, Raviv, Propper and Schachter Fink (2003) and Raviv and Weiner (1995) in Israel; Christiansen (1986) in Norway; Alekspolsky and Kostrikina (2007) in Russia; Stones (1996) in South Africa; Berenguer and Quintanilla (1994), Hidalgo, De Nicolás and Yllá (1991), Seisdedos (1983) and Yllá and Hidalgo (2003) in Spain; Faberman (1997), Janda, England, Lobejoy and Drury (1998), Nevas and Farber (2001), Rose (2003), Schindler, Berren, Mo, Beigel and Santiago (1987) and Wood, Jones and Benjamin (1986) in the United States, among others. There are also studies which compare clinical psychology and other health sciences (Dollinger \& Thelen, 1978; Hidalgo et al., 1991; Janda et al., 1998; Murray, 1962; Nunnally \& Kittross, 1958; Small \& Gault, 1975; Tallent \& Reiss, 1959; Thumin \& Zebelman, 1962; Webb \& Speer, 1985; Wood et al., 1986), the image of psychology among psychology students (Alvarez-Castro, Buela-Casal \& Sierra, 1995; Freixa i Baqué, 1984, 1985; García, Pérez, Gutiérrez, Gómez \& Bohórquez, 2004; Oliver, Bernstein anderson, Blashfield \& Roberts, 2004; Sans de Uhlandt et al., 1997; Sierra, Alvarez-Castro \& Buela-Casal, 1994; Sierra \& Freixa, 1993; Sierra, Pal-Hegedüs, Alvarez-Castro \& Freixa i Baqué, 1995; Turner \& Quinn, 1999) and the image of psychology among physicians and psychologists (see for example: Harnett, Simonetta \& Mahoney, 1989 and Von Sidow \& Reimer, 1998).
The importance of psychology in medical settings has been demonstrated to the point that there are thousands of psychologists who teach medical students in the U.S., which is crucial for their education, as it makes them to be better physicians (Wedding, 2008). The incorporation of Psychology in the medical curricula makes evident that it is necessary for the medical students and furthermore, for the patients. Additionally, there are special training programs, as for example one in which the clinical psychologists and pediatric residents collaborate in prevention of abuse (Weaver, Hughes, Friedman, Edwars \& Holmes, 2006). As both, medicine and psychology have the same purpose of providing wellbeing of the people, the medical students need to learn a lot of psychology (Reig-Ferrer, 2005). Once again, it can be concluded that the psychologists are indispensable in the medical settings. This can be understood as another reason to consider whether psychology should be recognized as a health profession. Holden (1996) has even proposed a new terminology according to which a degree of psychological physician would be granted. According to the author, the psychologists would be considered, as it should be, as well-trained and prepared members of the health teams.

All the articles described above, published in prestigious scientific journals are related to the relation between psychology and health professions. Some of them indicate clearly that psychology is a health profession and this point of view is promoted. There are even journals, for example, Journal of Clinical Psychology in Medical Settings, which have been created and are edited for this purpose (see for example Rozensky, 2006). Also, the psychologists themselves have been demanding the recognition of the field as a health profession, which can be seen on the example of Spain, where this fight has started in the seventies (Duro, 2004).

A series of studies conducted in Spain by BuelaCasal and collaborators have examined the image of psychology as a health profession among the university teachers of psychology and medicine (Buela-Casal, Gil Roales-Nieto et al., 2005), the Spanish psychologists (Buela-Casal, Bretón-López et al., 2005), psychology students (Sierra et al., 
2005) and general population (Buela-Casal, Teva et al., 2005). It has been shown that the teachers of medicine have more favorable opinion, in comparison to the psychology teachers, about the inclusion of medicine and psychology in the same field and both samples include clinical psychology and medicine in the same field (Buela-Casal, Gil Roales-Nieto et al., 2005). Additionally, most of the Spanish psychologists consider their discipline as a health profession (Buela-Casal, Bretón-López et al., 2005), which is also the case of the students, even to a higher degree in the latter case (Sierra et al., 2005). Another important finding is that the general population also sees psychology as a health profession (Buela-Casal, Teva et al., 2005).

Taking into account the importance of the subject and the previous studies conducted in Spain, which evaluated if psychology was seen as a health profession, the current study can be considered as a continuation, which examined whether psychology is seen as a health profession on a sample of psychologists worldwide. As in the case of the studies conducted in Spain by Buela-Casal and collaborators (See Buela-Casal, 2005), the authors decided not to give the personal opinions and all the paper has been edited as a description of the present situation and the results. Thus, the readers have the opportunity to draw their own conclusion without being influenced by the opinion of the authors. Moreover, to our knowledge, this is the first study conducted at international level and with a large sample, representative for the scientific community in the field of psychology all over the world.

\section{Method}

\section{Participants}

The current study used a sample of 803 psychologists from 42 countries, 23 psychology major fields and 32 orientations, randomly selected from the Web of Science database with the criterion of having published at least one article in a journal included in this database, under the categories of clinical psychology and multidisciplinary psychology. The mean age of the participants was 49 years
TABLE 1

The 10 Most Frequent Profiles of the Participants

\begin{tabular}{lc}
\hline \multicolumn{1}{c}{ Country } & Number of participants (\%) \\
\hline United States & $431(53.67)$ \\
Canada & $58(7.22)$ \\
United Kingdom & $56(6.97)$ \\
Germany & $38(4.73)$ \\
Netherlands & $32(3.98)$ \\
Australia & $28(3.49)$ \\
Sweden & $23(2.86)$ \\
Italy & $17(2.11)$ \\
Israel & $14(1.74)$ \\
Spain & $12(1.49)$ \\
\hline
\end{tabular}

Major field of psychology Number of participants (\%)

\begin{tabular}{lc}
\hline Clinical Psychology & $328(40.84)$ \\
Health Psychology & $91(11.33)$ \\
Clinical Neuropsychology & $47(5.85)$ \\
Social Psychology & $40(4.98)$ \\
Clinical Child Psychology & $40(4.98)$ \\
Neuroscience & $32(3.98)$ \\
Developmental Psychology & $27(3.36)$ \\
Experimental Psychology & $20(2.49)$ \\
Psychopharmacology & $19(2.37)$ \\
Counselling Psychology & $18(2.24)$ \\
Cognitive Psychology & $18(2.24)$
\end{tabular}

\begin{tabular}{lc}
\hline \multicolumn{1}{c}{ Orientation } & Number of answers (\%) \\
\hline Cognitive-Behaviorism & $320(42.55)$ \\
Biological psychology & $74(9.84)$ \\
Eclectic psychology & $61(8.11)$ \\
Social psychology & $58(7.71)$ \\
Behaviorism & $48(6.38)$ \\
Developmental Psychology & $41(5.45)$ \\
Cognitivism & $32(4.26)$ \\
Psychoanalysis & $24(3.19)$ \\
Experimental analysis of & $23(3.06)$ \\
behavior & $18(2.39)$ \\
Systemic psychology & Eumber of participants (\%) \\
\hline \multicolumn{1}{c}{ Experience } & $152(19.17)$ \\
Less than 10 & $273(34.43)$ \\
Between 10 and 20 & $207(26.10)$ \\
Between 20 and 30 & $145(18.28)$ \\
Between 30 and 40 & $19(2.40)$ \\
Between 40 and 50 & $7(0.88)$ \\
More than 50 &
\end{tabular}

Source: Own work.

$(S D=11.07), 40 \%$ were women and $60 \%$ men. The sample is representative with the confidence level of $92 \%$ and the estimation error is 3\%. Clini- 
TABLE 2

The Questionnaire about the Image of Psychology as a Health Profession, based on Bretón-López et al. (2005)

The information provided in the questionnaire is completely ANONIMOUS; there is no need to include any identification data, as names, address, e-mail etc.

Please read carefully the following questions and mark the box that corresponds with your opinion.

Sex:

Age:

Years of experience Psycho-

Country:

logy Major Field:

1. Psychologist can help to prevent health problems

Orientation:

2. Psychology and Medicine are sciences which belong to the same field of knowledge

3. Clinical Psychology and Medicine are sciences that belong to the same field of knowledge

4. Any psychologist is qualified to diagnose mental problems

5. The clinical psychologists are qualified to diagnose mental problems

6. Psychology is closer to Medicine than to other fields of knowledge

7. Any type of psychologist is qualified to treat emotional and mental problems that affect health

8. Clinical psychologists are qualified to treat emotional and mental problems that affect health

9. Psychology can help to improve people's health

Yes No I do not know

Yes No I do not know

Yes No I do not know

Yes No I do not know

Yes No I do not know

Yes No I do not know

Yes No I do not know

10. The work of the psychiatrist and the psychologist is very similar

11. The work of the psychiatrist and the clinical psychologist is very similar

12. Psychologists should form part of professional teams in hospitals

13. Clinical psychologists should form part of professional teams in hospitals

14. One of the central aspects of Psychology is to promote healthy behaviours

15. Psychologists are as qualified as psychiatrists for making expert assessment in the legal context

16. Psychologists specialized in psychopharmacology should be authorized to prescribe medicines

Yes No I do not know

Yes No I do not know

Yes No I do not know

Yes No I do not know

Yes No I do not know

Yes No I do not know

Yes No I do not know

Yes No I do not know

Yes No I do not know

Please indicate the similarity between the following disciplines in a scale from 0 to 4 where 0 means no similarity and 4 means the highest similarity.

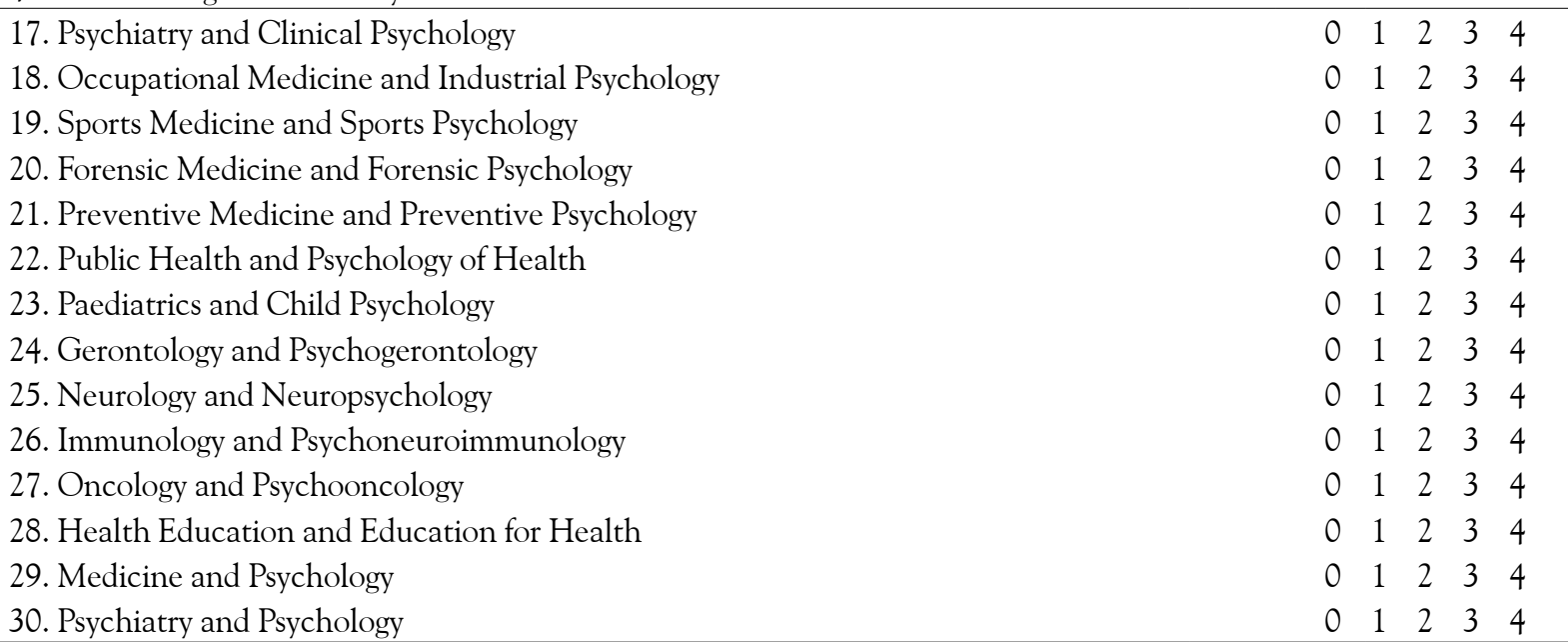

Source: Own work.

cal and multidisciplinary journals were chosen as these are the categories where most of the research in psychology related to health and medical settings are published. The scientists who publish in these journals are considered experts in the field with the most valid opinion. 
Although psychology is practiced in most of the countries, it is not equally well established in different parts of the world. Most of the research in the field is conducted in very few countries. Thus, this randomly selected sample reflects this international reality in the field.

As can be seen in Table 1, the most predominant profile of the participants consists on subjects from the United States (53.67\%), defining themselves as clinical psychologists (40.84\%) with between 10 and 20 years of experience (34.43\%).

\section{Instruments}

The current survey was conducted by means of a self-informed questionnaire created by BretónLópez et al. (2005) called Opinion Questionnaire on Psychology as a Health Profession (Cuestionario de Opinión sobre la Psicología como Profesión Sanitaria, COPPS).

The questionnaire was translated into English and the questions on the respondents' major field of psychology, orientation and country were added (See Table 2). The aim of the questionnaire was to study whether psychology is seen as a health profession and whether some different areas of psychology and medicine are seen as similar alike (Buela-Casal, Bretón-López et al., 2005).

The questionnaire consisted of two parts. The first part included 15 original questions related to the image of psychology, the similarity between psychology and medicine and psychologists as health professionals with three different types of answer: "yes", "no" and "I do not know". The higher the score in the questionnaire, the more favorable the opinion on psychology as a health profession is. A question "Psychologists specializing in psychopharmacology should be authorized to prescribe medicines" was added. The second part consists of 14 questions in which the participants evaluate the similarity between different areas of psychology and medicine with a response Likert format from 0 to 4 , where 0 means no similarity and 4 means the highest similarity. The analysis conducted with the worldwide sample of psychologists in the present study shows that the alpha value for the first scale is 0.94 and for the second scale is 0.9. The questionnaire was provided via a website designed to assure the anonymity.

Design

The current work is a study of populations through surveys, following the classification by Montero and León (2007) edited according to the norms established by Ramos-Álvarez, Moreno-Fernández, Valdés-Conory and Catena (2008).

\section{Procedure}

The e-mail addresses of the scientists who have published at least one article in a psychology journal indexed in the Web of Science database between 2005 and 2006 in the categories of clinical psychology and multidisciplinary psychology were obtained. The total number of 803 valid answers were collected.

A program designed for the study enabled automatic incorporation of the answers in a database. Each participant could answer the questionnaire only once.

\section{Results}

Table 3 shows the percentages of "yes" and "no" answers to the questions about the character of psychology as a health profession, taking into account the answers of all the participants. The results reveal that most of the answers are in favor of considering psychology as a health profession. Although the answers to questions No 2, 4, 6, 7 and 10 are mostly negative, the difference in yes/ no answers in question No 2 is slight and shows differences among countries (see Table 4). In questions No 4, 7 and 10 ("Any psychologist is qualified to diagnose mental problems", "Any type of psychologist is qualified to treat emotional and mental problems that affect health" and "The work of the psychiatrist and the psychologist is very similar") the percentages of "no" answers $(92.73 \%, 94.86 \%$ and $85.41 \%$, respectively) are clearly higher than the percentages of "yes" answers (6.02\%, 4.39\% 
TABLE 3

Percentages of the "Yes", "No" and "I Do Not Know"Answers of the Whole Analyzed Sample about the Image of Psychology as a Health Profession

\begin{tabular}{lccc}
\hline \multicolumn{1}{c}{ Item } & Yes & No & $\begin{array}{c}\text { I do not } \\
\text { know }\end{array}$ \\
\hline 1. Psychologist can help to prevent health problems & 98.24 & 0.88 & 0.88 \\
2. Psychology and Medicine are sciences which belong to the same field of knowledge & 45.17 & 49.69 & 5.14 \\
3. Clinical Psychology and Medicine are sciences that belong to the same field of knowledge & 59.37 & 36.10 & 4.53 \\
4. Any psychologist is qualified to diagnose mental problems & 6.02 & 92.73 & 1.25 \\
5. The clinical psychologists are qualified to diagnose mental problems & 91.34 & 4.77 & 3.89 \\
6. Psychology is closer to Medicine than to other fields of knowledge & 35.46 & 50.5 & 14.04 \\
7. Any type of psychologist is qualified to treat emotional and mental problems that affect & 4.39 & 94.86 & 0.75 \\
health & & & \\
8. Clinical psychologists are qualified to treat emotional and mental problems that affect & 92.68 & 4.29 & 3.03 \\
health & 97.87 & 1.51 & 0.63 \\
9. Psychology can help to improve people's health & 9.69 & 85.41 & 4.91 \\
10. The work of the psychiatrist and the psychologist is very similar & 55.79 & 40.18 & 4.03 \\
11. The work of the psychiatrist and the clinical psychologist is very similar & 64.74 & 27.46 & 7.81 \\
12. Psychologists should be part of professional teams in hospitals & 95.48 & 1.51 & 3.01 \\
13. Clinical psychologists should be part of professional teams in hospitals & 80.08 & 16.02 & 3.91 \\
14. One of the central aspects of Psychology is to promote healthy behaviors & 74.27 & 15.13 & 10.59 \\
15. Psychologists are as qualified as psychiatrists for making expert assessment in the legal & & & \\
context & 43.49 & 37.80 & 18.71 \\
\hline 16. Psychologists specialized in psychopharmacology should be authorized to prescribe me- \\
dicines
\end{tabular}

Note. The questions with more yes than no answers are in bold. Source: Own work.

and $9.69 \%$, respectively). On the other hand, the percentages of "yes" answers to questions No 1, 3, $5,8,9,12,13,14$ and 15 are clearly higher than the percentages of the "no" answers $(98.24 \%$ to $0.88 \%$, $59.37 \%$ to $36.10 \%, 91.34 \%$ to $4.77 \%, 92.68 \%$ to $4.29 \%, 97.87 \%$ to $1.51 \%, 64.74 \%$ to $27.46 \%, 95.48 \%$ to $1.51 \%, 80.08 \%$ to $16.02 \%$ and $74.27 \%$ to $15.13 \%$, respectively). The answers to questions No 11 and 16 are also "yes" (55.79\% to $40.18 \%$ and $43.49 \%$ to $37.8 \%$ respectively) although the difference is slight. The highest percentage of the "I do not know" answers has been found in question No 16 ("Psychologists specialized in psychopharmacology should be authorized to prescribe medicines").

Figure 1 shows the answers of the whole sample to the items of the second subscale of the questionnaire, which examines the similarity between different areas of psychology and medicine.

The mean responses for the second subscale are generally high and the highest similarity is perceived for the disciplines: psychiatry-clinical psychology and health education-education for health.

In relation to the first subscale, the results show differences between the percentages of "yes" and "no" answers among the analyzed countries in items No 2, 6, 10, 11, 15 and 16. The next step consisted of calculating the mean scores in the first subscale for each country analyzed. The "yes" answers were assigned 1, the "no" answers were assigned 0 and the "I do not know" answers were not used, as it is difficult to interpret their significance. Taking into account that there are 16 items, the maximum score would be 16 , which would mean that the opinion is completely in favor and the minimum score would be 0 , which would mean completely against opinion on the subject. Because of differences in numbers of participants by countries and thus lack of homogeneity of variances, a non-parametric Kruskal-Wallis test was performed to make comparisons among countries. The test shows that there are significant 


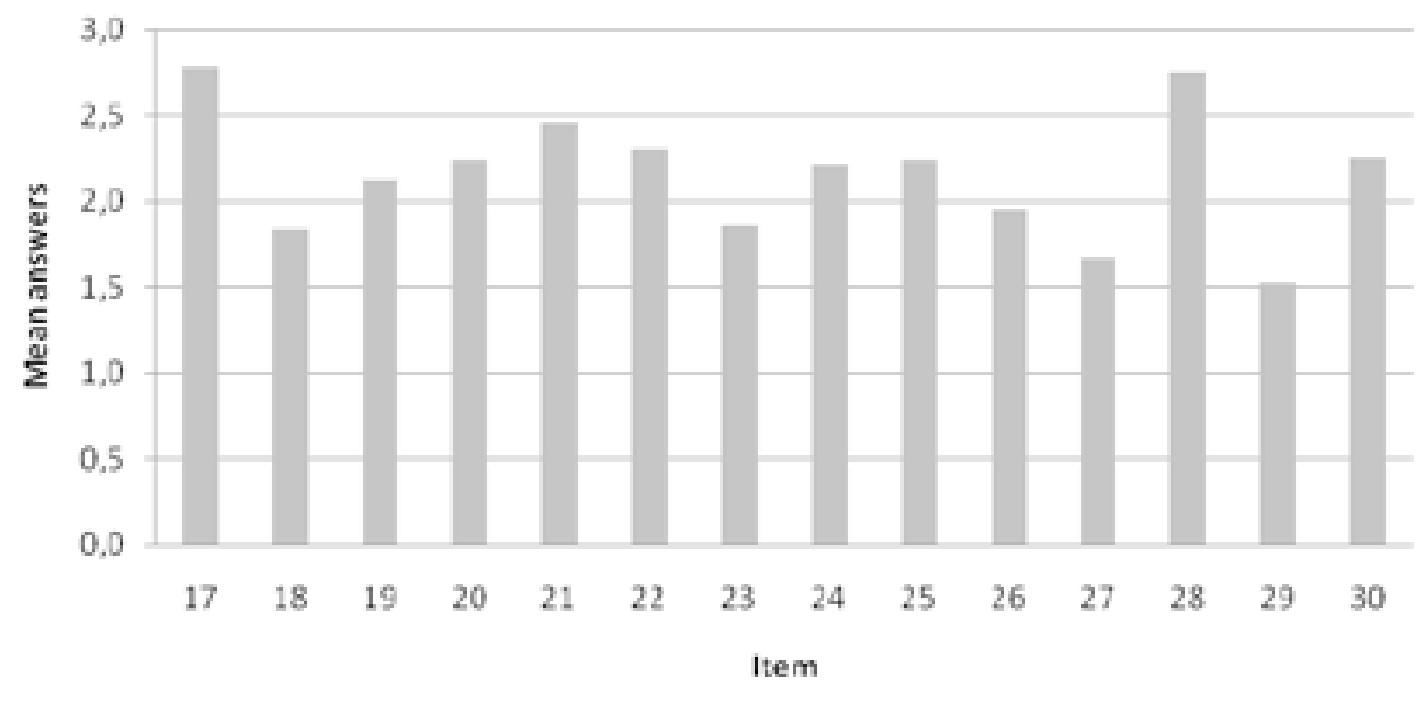

Figure 1. Comparison of the mean answers to the items about the similarity between different disciplines of psychology and medicine.

Note. Items: 17. Psychiatry and Clinical Psychology, 18. Occupational Medicine and Industrial Psychology, 19. Sports Medicine and Sports Psychology, 20. Forensic Medicine and Forensic Psychology, 21. Preventive Medicine and Preventive Psychology, 22. Public Health and Psychology of Health, 23. Paediatrics and Child Psychology, 24. Gerontology and Psychogerontology, 25. Neurology and Neuropsychology, 26. Immunology and Psychoneuroimmunology, 27. Oncology and Psychooncology, 28. Health Education and Education for Health, 29. Medicine and Psychology, 30. Psychiatry and Psychology.

Source: Own work.

differences between the countries in the mean scores of the subscales 1 and 2 (see Table 4). Also the means in all the groups in a scale from 0 to 10 are shown to make possible the comparison between groups.
Nevertheless, Games-Howell post-hoc tests show the only significant difference in the Subscale 2 which was found between the United States and Other (Mean difference $=3.80, p=0.01$ ).

\section{TABLE 4}

Differences between Countries in the Subscale 1 and the Subscale 2

\begin{tabular}{|c|c|c|c|c|c|c|}
\hline \multirow[b]{2}{*}{ Country } & \multicolumn{3}{|c|}{ Subscale 1} & \multicolumn{3}{|c|}{ Subscale 2} \\
\hline & Mean & $\begin{array}{c}\text { Mean } \\
\text { (Scale 0-10) }\end{array}$ & $\begin{array}{l}\text { Standard } \\
\text { deviation }\end{array}$ & Mean & $\begin{array}{c}\text { Mean } \\
\text { (Scale 0-10) }\end{array}$ & $\begin{array}{l}\text { Standard } \\
\text { deviation }\end{array}$ \\
\hline Australia & 10.04 & 6.27 & 2.53 & 29.75 & 5.31 & 10.55 \\
\hline Canada & 9.12 & 5.70 & 2.44 & 28.64 & 5.11 & 7.87 \\
\hline Germany & 9.26 & 5.79 & 2.11 & 27.95 & 4.99 & 6.72 \\
\hline Israel & 8.93 & 5.58 & 2.5 & 27.36 & 4.89 & 10.2 \\
\hline Italy & 7.82 & 4.89 & 2.07 & 24.94 & 4.45 & 8.01 \\
\hline Netherlands & 9.47 & 5.92 & 2.11 & 29.25 & 5.22 & 7.1 \\
\hline Spain & 10.75 & 6.72 & 4.05 & 30.58 & 5.46 & 10.63 \\
\hline Sweden & 9.13 & 5.71 & 2.62 & 28.3 & 5.05 & 7.01 \\
\hline United Kingdom & 9.3 & 5.81 & 1.73 & 29.75 & 5.31 & 7.87 \\
\hline United States & 9.67 & 6.04 & 2.03 & 30.27 & 5.41 & 8.39 \\
\hline Other & 9.53 & 5.96 & 1.96 & 26.4 & 4.71 & 7.3 \\
\hline$\chi^{2} 10$ value $(* p<0.05)$ & & $25.65 *$ & & & $24.2 *$ & \\
\hline
\end{tabular}

Source: Own work. 


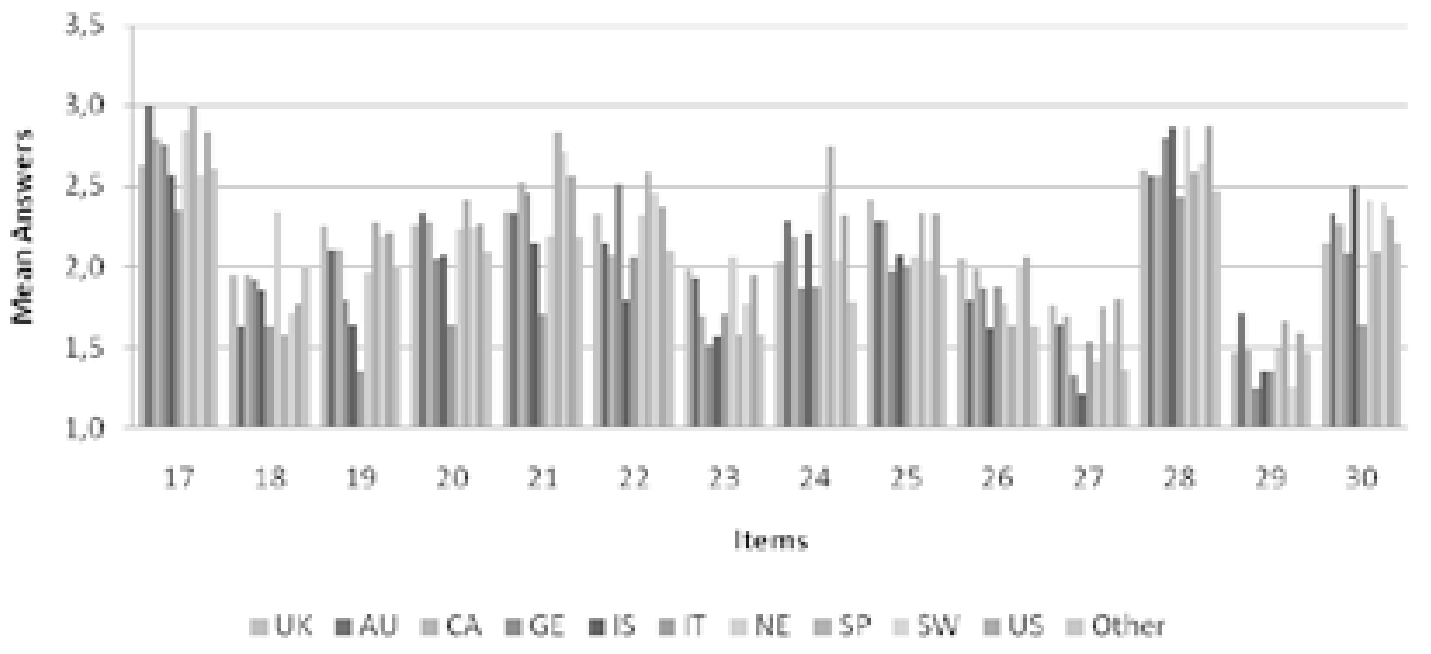

Figure 2. Comparison of the mean answers to the items about the similarity between different disciplines of psychology and medicine in different countries.

Note. AU - Australia, CA - Canada, GE - Germany, IS - Israel, IT - Italy, NE - Netherlands, SP - Spain, SW - Sweden, UK United Kingdom

Items: 17. Psychiatry and Clinical Psychology, 18. Occupational Medicine and Industrial Psychology, 19. Sports Medicine and Sports Psychology, 20. Forensic Medicine and Forensic Psychology, 21. Preventive Medicine and Preventive Psychology, 22.

Public Health and Psychology of Health, 23. Paediatrics and Child Psychology, 24. Gerontology and Psychogerontology, 25.

Neurology and Neuropsychology, 26. Immunology and Psychoneuroimmunology, 27. Oncology and Psychooncology, 28. Health Education and Education for Health, 29. Medicine and Psychology, 30. Psychiatry and Psychology.

Source: Own work.

Figure 2 shows the opinions about the similarities of the different medical and psychological disciplines of the ten countries with the highest number of participants, along with the other category for the rest of countries. The countries that show the greatest differences with respect to the rest are: Italy, with many answers lower than the rest and Spain, with more extreme answers in comparison to the rest.

Kruskal-Wallis analysis of the second subscale, when the mean scores for all the items are calculated, shows significant differences between the countries, where Spain is the country where most similarity is perceived and Italy is the country with the least perceived similarity (see Figure 2).

The same 0 (no) and 1 (yes) assignation was conducted in case of different disciplines in psychology. The Kruskal-Wallis analysis shows that there are significant differences between the psychology major fields (see Table 5). Post-hoc Games-Howell tests show significant differences in the Subscale 1 between Clinical Child Psychology and Psychopharmacology (Mean difference $=1.93, p=0.018$ ),
Clinical Neuropsychology and Psychopharmacology (Mean difference $=2.47, p=0.001$ ), Clinical Neuropsychology and Other (Mean difference $=1.18$, $p=0.042$ ) and Clinical Psychology and Psychopharmacology (Mean difference $=1.69, p=0.028$ ) For the Subscale 2, significant differences were found between Clinical Child Psychology and Psychopharmacology (Mean difference $=11.62$, $p=0.002$ ), Clinical Neuropsychology and Psychopharmacology (Mean difference $=12.89$, $p<0.001$ ), Clinical Psychology and Psychopharmacology (Mean difference $=10.58, p=0.002$ ), Cognitive Psychology and Psychopharmacology (Mean difference $=11.82, p=0.004$ ), Counseling Psychology and Psychopharmacology (Mean difference $=12.15, p=0.004)$, Developmental Psychology and Psychopharmacology (Mean difference $=12.61, p=0.001)$ and Health Psychology and Psychopharmacology (Mean difference $=10.68$, $p=0.002$ ).

Figure 3 shows the mean scores in the similarity between different disciplines of psychology and 
TABLE 5

Differences between Psychology Major Fields in the Subscale 1 and the Subscale 2

\begin{tabular}{|c|c|c|c|c|c|c|}
\hline \multirow[b]{2}{*}{ Field } & \multicolumn{3}{|c|}{ Subscale 1} & \multicolumn{3}{|c|}{ Subscale 2} \\
\hline & Mean & $\begin{array}{c}\text { Mean } \\
\text { (Scale 0-10) }\end{array}$ & $\begin{array}{l}\text { Standard } \\
\text { Deviation }\end{array}$ & Mean & $\begin{array}{c}\text { Mean } \\
\text { (Scale 0-10) }\end{array}$ & $\begin{array}{l}\text { Standard } \\
\text { Deviation }\end{array}$ \\
\hline Clinical Child Psychology & 9.78 & 6.11 & 1.72 & 30.3 & 5.41 & 8.37 \\
\hline Clinical Neuropsychology & 10.3 & 6.44 & 1.76 & 31.83 & 5.68 & 8.34 \\
\hline Clinical Psychology & 9.54 & 5.96 & 2.18 & 29.13 & 5.20 & 7.7 \\
\hline Cognitive Psychology & 9.5 & 5.94 & 2.01 & 30.5 & 5.45 & 7.39 \\
\hline Counseling Psychology & 9.83 & 6.15 & 2.15 & 30.83 & 5.51 & 7.63 \\
\hline Developmental Psychology & 9.63 & 6.02 & 2.56 & 31.3 & 5.59 & 8.48 \\
\hline Experimental Psychology & 8.95 & 5.59 & 1.93 & 27.8 & 4.96 & 9.7 \\
\hline Health Psychology & 9.33 & 5.83 & 2.16 & 29.37 & 5.24 & 8.12 \\
\hline Neuroscience & 9.09 & 5.68 & 2.68 & 26.66 & 4.76 & 11.49 \\
\hline Psychopharmacology & 7.84 & 4.9 & 1.8 & 18.68 & 3.34 & 8.79 \\
\hline Social Psychology & 10 & 6.25 & 1.72 & 30.48 & 5.44 & 7.09 \\
\hline Other & 9.13 & 5.71 & 2.27 & 30.54 & 5.45 & 9.19 \\
\hline$\chi^{2} 11$ Value $(* p<0.05)$ & & $26.35^{*}$ & & & $30.55^{*}$ & \\
\hline
\end{tabular}

Source: Own work.

medicine among the ten fields with the highest numbers of participants. In the similar way as in the case of the first subscale, most of the fields show similar pattern of responses. Nevertheless, the answers of psychologists who define themselves as belonging to the neuroscience field seem lower than the rest and the answers of the psychopharmacologists are much lower than the rest, which means that they see much less similarity between different fields of psychology and medicine.

\section{Discussion}

This study is a continuation of the studies conducted by Buela-Casal and collaborators who have examined the image of psychology as a health profession among the university teachers of psychology and medicine (Buela-Casal, Gil Roales-Nieto et al., 2005), Spanish psychologists (Buela-Casal, BretónLópez et al., 2005), psychology students (Sierra et al., 2005) and the general population (Buela-Casal, Teva et al., 2005) but this time using a worldwide sample of 803 scientists from 42 different countries and 23 psychology major fields who have published at least one article in the most prestigious clinical and multidisciplinary psychology journals in the world. Thus, it can be concluded that the present paper shows the opinion of the world scientific community of psychologists. The results of this study show similarity with the studies previously conducted in Spain and the opinion on psychology as a health profession is quite similar in different countries. The current study shows that the participants from the United States see more similarities between psychology and medicine than the subjects from other countries with small number of participants. Another interesting finding is that Psychopharmacology is the field with the smallest perceived similarity.

The image of psychology as a health profession in a worldwide sample of psychologists is mostly in favor. Moreover, clinical psychology is the field that obtained the highest scores. This should be taken into account in some countries, as for example in Spain where almost $70 \%$ of all the psychologists define themselves as clinical psychologist (Santolaya Ochando, Berdullas Temes \& Fernández Hermida, 2002) and only about 100 of 45,000 psychology students a year have the possibility to be recognized as health professionals. Of course, it is understood that non-health professionals cannot treat patients and are not 


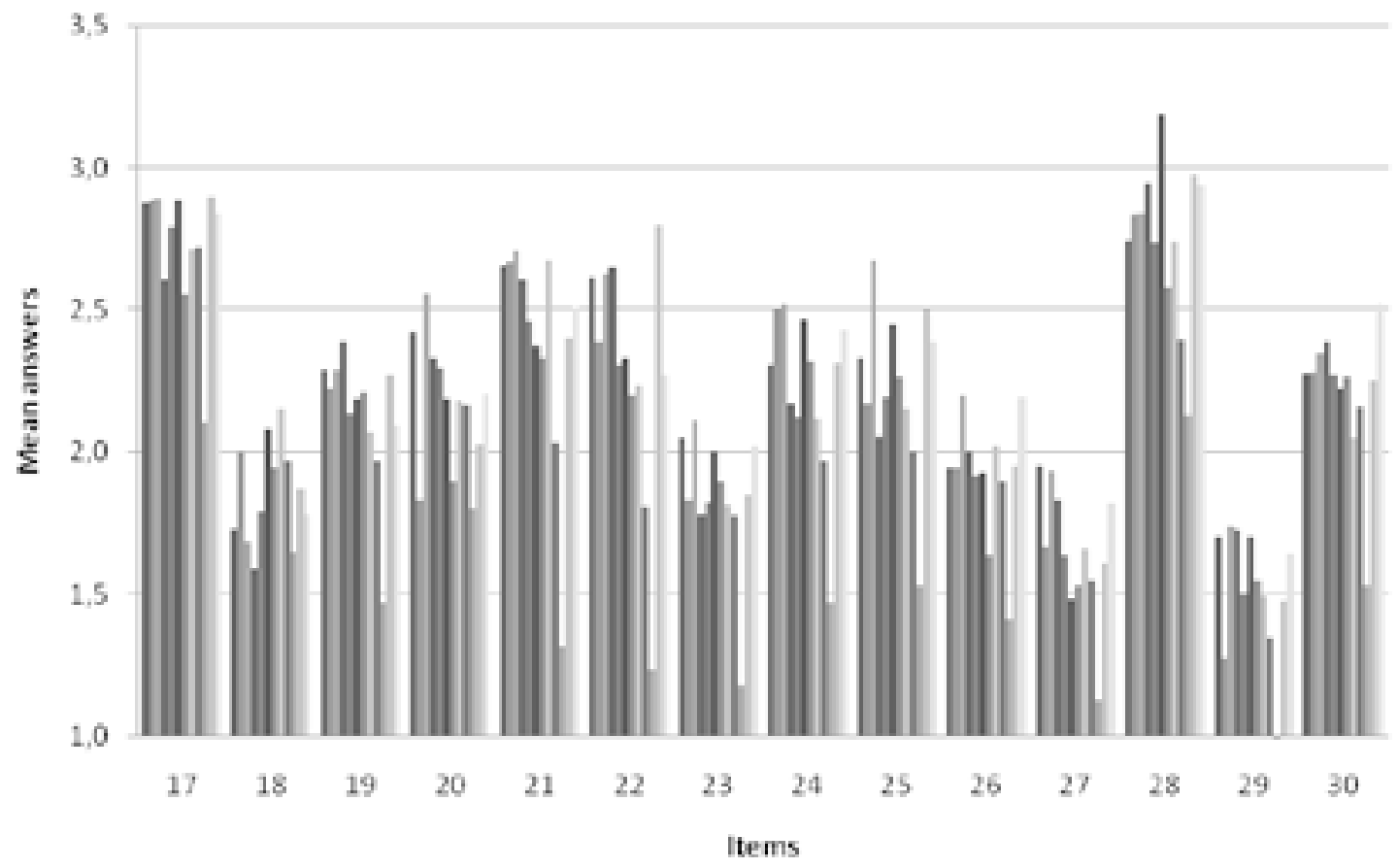

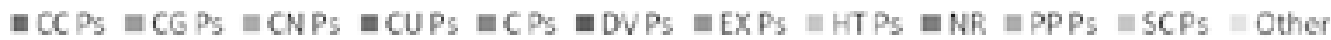

Figure 3. Comparison of the mean answers to the items about the similarity between different disciplines of psychology and medicine among the fields.

Note: CC Ps - Clinical Child Psychology, CG Ps - Cognitive Psychology, CN Ps - Clinical Neuropsychology, CU Ps - Counseling Psychology, C Ps - Clinical Psychology, EX Ps - Experimental Psychology, HT Ps - Health Psychology, NR - Neuroscience, PP Ps - Psychopharmacology, SC Ps - Social Psychology.

Items: 17. Psychiatry and Clinical Psychology, 18. Occupational Medicine and Industrial Psychology, 19. Sports Medicine and Sports Psychology, 20. Forensic Medicine and Forensic Psychology, 21. Preventive Medicine and Preventive Psychology, 22. Public Health and Psychology of Health, 23. Paediatrics and Child Psychology, 24. Gerontology and Psychogerontology, 25. Neurology and Neuropsychology, 26. Immunology and Psychoneuroimmunology, 27. Oncology and Psychooncology, 28. Health Education and Education for Health, 29. Medicine and Psychology, 30. Psychiatry and Psychology.

Source: Own work.

integrated in the health system. The current paper can help in changing this situation.

The findings of the current paper are crucial for the promotion of psychology as a health profession. It is considered that the psychologists themselves, who know very well their profession, can give the most valid opinion on where it should be classified. For the first time, an opinion of a large sample of specialists from all over the world was collected. This way, the psychologist from different countries will have a scientific basis to claim more presence and consideration in medical settings.

Taking into account that psychology is still a young profession, there are differences between the countries. At least in Europe, the differences in the university training of the psychologists will disappear with the creation of the European Space for Higher Education. For this reason it is crucial to establish whether it is a health profession as this factor affects the decisions that need to be made for the training. This paper can also help to unify the whole discipline. Nowadays, with the process of globalization and a free flow of information between most of the countries, at least in the occidental culture a person who would go, for example, to an oncologist would receive more or less the same treatment either in the U.S., Spain, Germany, Australia etc. They would also know what kind of specialist they are consulting and it would be more or less the same in all the countries. The current 
work is crucial for the unification of the discipline, as it shows the opinion of the whole scientific community of psychologists.

The consideration of psychology as a health profession requires some changes in education of the professionals. It has been proposed that students need to learn more medical knowledge, as they already work in health centers (Belar, 2008). The new curricula in the doctoral studies are crucial for the future of the profession (Santolaya, 2001). In the current study, it has been clearly shown that psychology should be related to health. The data should be taken into account and used when planning the future of our profession.

As can be seen on the example of a paper by Haynes, Yoshioka, Pinson and Kloezeman (2005) psychology has played an important role in the development of the empirically supported treatments for adult behavior disorders. The next step would consist of reviewing the worldwide unification of the category where psychology is included. This study can serve as a guide to achieving this purpose. Although it seems that psychology is considered a health profession, different countries and organizations still underestimate its importance in the field. Now, for the first time, the psychologists have data to claim this recognition. Thus, according to this study, at least clinical psychology should be recognized a health profession all over the world and have the same rights and duties as other health professions.

\section{References}

Alekspolsky, A. A. \& Kostrikina, I. S. (2007). International forum "Image of Russian psychology in country's regions and in the world". Psikhologicheskii zhurnal, 28, 124-129.

Alvarez-Castro, S., Buela-Casal, G. \& Sierra, J. C. (1995). Situación actual del modelo conductual en España. Revista de Psicología Contemporánea, 1(2), 80-91.

Belar, C. D. (2008). Changing educational needs of psychologists: Do we need more medical knowledge, basic science and more psychological science?
Journal of Clinical Psychology in Medical Settings, 15(1), 12-17.

Berenguer, G. \& Quintanilla, I. (1994). La imagen de la Psicología y los psicólogos en el Estado español. Papeles del Psicólogo, 58, 41-68.

Bretón-López, J., Bermúdez, M. P., Teva, I., Gil RoalesNieto, J., Sierra, J. \& Buela-Casal, G. (2005, July). Propiedades psicométricas del cuestionario de opinión acerca de la Psicología como profesión sanitaria. Paper presented at the V Congreso Iberoamericano de Evaluación Psicológica, Buenos Aires, Argentina.

Buela-Casal, G. (2004). La Psicología: iuna profesión sanitaria con distintas especialidades? [Special Issue]. INFOCOP, 103-111.

Buela-Casal, G. (2005). iLa psicología es una profesión sanitaria? Papeles del Psicólogo, 26(91), 2-3.

Buela-Casal, G., Bretón-López, J., Agudelo, D., Bermúdez, M. P., Sierra, J. C., Teva, I., et al. (2005). Imagen de la psicología como profesión sanitaria en psicólogos españoles. Papeles del Psicólogo, 26(91), 16-23.

Buela-Casal, G., Gil Roales-Nieto, J., Sierra, J. C., Bermúdez, M. P., Agudelo, D., Breton-López, J., et al. (2005). Imagen de la psicología como profesión sanitaria en profesores universitarios de psicología y de medicina. Papeles del Psicólogo, 26(91), 4-15.

Buela-Casal, G., Teva, I., Sierra, J. C., Bretón-López, J., Agudelo, D., Bermúdez, M. P., et al. (2005). Imagen de la psicología como profesión sanitaria entre la población general. Papeles del Psicólogo, 26(91), 30-38.

Christiansen, B. (1986). The public image of psychologists in Norway. Tidsskrift for Norsk Psykologforening, 23, 619-634.

Dempsey, S. (2007). The public perception of clinical psychologists: A discursive analysis. Australian Psychologist, 42(1), 2-14.

Dollinger, S. \& Thelen, M. H. (1978). Children`s perceptions of Psychology. Professional Psychology, February, 117-126.

Duro, J. C. (2004). Apuntes históricos: la Psicología como profesión sanitaria [Special Issue]. INFOCOP, 7-11.

Faberman, R. K. (1997). Public attitudes about psychologists and mental health care: Research to guide 
the American Psychological Association public education campaign. Professional Psychology: Research and Practice, 28(2), 128-136.

Freixa i Baqué, E. (1984). Evolution de l'image de la Psychologie chez les étudiants en Psychologie. Psychologie Française, 29(2), 209-212.

Freixa i Baqué, E. (1985). Epistémologie implicite chez les étudiants en Psychologie. Technologie et Thérapie du Comportement, 9(1), 61-70.

Friedlmayer, S. \& Rössler, E. (1995). Professional identity and public image of Austrian psychologists. In A. Schorr \& S. Saari (Eds.), Psychology in Europe: Facts, figures, realities (pp. 165-179). London: Hogrefe \& Huber.

García, A., Pérez, V., Gutiérrez, M. T, Gómez, J. \& Bohórquez, C. (2004). Algunas consideraciones en torno a la Psicología por parte de los estudiantes y profesores de la licenciatura y de universidades en general. Revista de Psicología General y Aplicada, 57(1), 113-127.

Harnett, J., Simonetta, L. \& Mahoney, J. (1989). Perceptions of nonclinical psychologists toward Clinical Pscyhology and clinical psychologists. Professional Psychology: Research and Practice, 20(3), 187-189.

Hartwig, S. G. \& Delin, C. (2003). How unpopular are we? Reassessing psychologists` public image with different measures of favourability. Australian Psychologist, 38(1), 68-72.

Haynes, S., Yoshioka, D., Pinson, C. \& Kloezeman, K. (2005). El papel de la psicología en el desarrollo de tratamientos apoyados empíricamente para los trastornos conductuales en adultos. Papeles del Psicólogo, 26(91), 47-49.

Health Professions Council. (2010). Retrieved on July 10, 2010, from http://www.hpc-uk.org

Hidalgo, M. S., De Nicolás, L. \& Yllá, L. (1991). Visión de la imagen de la Psicología y del psicólogo en la población de Vizcaya. Psiquis, 12(4), 30-43.

Holden, M. S. (1996). The psychological physician: Semantics and survival. Journal of Clinical Psychology in Medical Settings, 3(2), 159-165.

Janda, L. H., England, K., Lovejoy, D. \& Drury, K. (1998). Attitudes toward Psychology relative other disciplines. Professional Psychology: Research and Practice, 29(2), 140-143.
Joseph, L., Gierlach, E., Housley, J. \& Beutler, L. (2005). La evolución de un campo: examen del desarrollo y la aceptación de la psicología clínica de la salud. Papeles del Psicólogo, 26(91), 39-46.

Montero, I. \& León, O. G. (2007). A guide for naming research studies in Psychology. International Journal of Clinical and Health Psychology, 7(3), 847-862.

Montin, S. (1995). The public image of psychologists in Finland. In A. Schorr \& S. Saari (Eds.), Psychology in Europe: Facts, figures, realities (pp. 181-203). London: Hogrefe \& Huber.

Murray, J. B. (1962). College students' concepts of psychologists and psychiatrists: A problem in differentiation. The Journal of Social Psychology, 57(1), 161-168.

Nevas, D. B. \& Farber, B.A. (2001). Parents' attitudes toward their childs's therapist and therapy. Professional Psychology: Research and Practice, 32(2), $165-170$.

Nunnally, J. \& Kittross, J. M. (1958). Public attitudes toward mental health professions. American Psychologist, 13(10), 589-594.

Oliver, M. N. I., Bernstein, J. H. anderson, K. G., Blashfield, R. K. \& Roberts, M. C. (2004). An exploratory examination of student attitudes toward "impaired" peers in Clinical Psychology training programs. Professional Psychology: Research and Practice, 35(2), 141-147.

Ramos-Álvarez, M. M., Moreno-Fernández, M. M., Valdés-Conory, B. \& Catena, A. (2008). Criteria of the peer-review process for publication of experimental and quasi-experimental research in Psychology: A guide for creating research papers, International Journal of Clinical and Health Psycho$\log y, 8(3), 751-764$.

Raviv, A., Raviv, A., Propper, A. \& Schachter Fink, A. (2003). Mothers' attitudes toward seeking help for their children from school and private psychologists. Professional Psychology: Research and Practice, 34(1), 95-101.

Raviv, A. \& Weiner, I. (1995). Why don`t they like us? Psychologists` public image in Israel during the Persian Gulf War. Professional Psychology: Research and Practice, 26(1), 88-94. 
Reig-Ferrer, A. (2005). ¿Qué debe saber un médico de Psicología? Análisis y Modificación de Conducta, 31(136-137), 273-311.

Rose, K. (2003). The public image of psychologists: Development and validation of an Attitudes toward Psychologists Scale. Dissertation Abstracts International: Section B: The Sciences \& Engineering, 63(7-B), 3463.

Rozensky, R. H. (2006). Clinical psychology in medical settings: Celebrating our past, enjoying the present, building our future. Journal of Clinical Psychology in Medical Settings, 13(4), 343-352.

Sans de Uhlandt, M. S, Rovella, A. T. \& Barbenza, C. M. (1997). La imagen del psicólogo en estudiantes de Psicología y en el público en general. Acta Psiquiátrica y Psicológica de América Latina, 43(1), 57-62.

Santolaya, F. (2001). Colegio y profesión. Papeles del Psicólogo, 80, 71-76.

Santolaya, F. (2010). [Editorial]. INFOCOP, 47, 2.

Santolaya Ochando, F., Berdullas Temes, M. \& Fernández Hermida, J. R. (2002). La década 1989-1998 en la Psicología española: análisis del desarrollo de la Psicología profesional en España. Papeles del Psicólogo, 82, 65-82.

Schindler, F., Berren, M. R, Mo, T. H., Beigel, A. \& Santiago, J. M. (1987). How to public perceives psychiatrists, psychologists, nonpsychiatric physicians and member of the clergy. Professional Psychology, 18(4), 371-376.

Seisdedos, N. (1983). Utilidad de la ciencia psicológica. Papeles del Psicólogo, 10-11, 27-34.

Sierra, J. C., Alvarez-Castro, S. \& Buela-Casal, G. (1994). Situación actual del psicoanálisis en España. Revista Latinoamericana de Psicología, 26(2), 189-203.

Sierra, J. C., Bermúdez, M. P., Teva, I., Agudelo, D., Bretón-López, J., Gutiérrez, O., et al. (2005). Imagen de la psicología como profesión sanitaria entre los estudiantes de psicología. Papeles del Psicólogo, 26(91), 24-29.

Sierra, J. C. \& Freixa, E. (1993). Estudio preliminar de la evolución de la imagen de la Psicología en estudiantes españoles de esta carrera. Psicothema, 5(1), 67-82.

Sierra, J. C., Pal-Hegedüs, C., Alvarez-Castro, S. \& Freixa i Baqué, E. (1995). Imagen de la Psicología en estudiantes de esta licenciatura de España y Costa Rica. Revista de Psicología Contemporánea, 2(2), 60-69.

Small, J. \& Gault, V. (1975). Perceptions of psychologists by the general public and three professional groups. Australian Psychologist, 10(1), 21-31.

Stones, C. R. (1996). Attitudes toward psychology, psychiatry and mental illness in the central Eastern Cape of South Africa. South African Journal of Psychology, 26(4), 221-225.

Tallent, N. \& Reiss, W. J. (1959). The public's concepts of psychologists and psychiatrists: A problem in differentiation. Journal of General Psychology, 61, 281-285.

Thumin, F. J. \& Zebelman, M. (1962). Psychology versus Psychiatry: A study of public image. American Psychologist, 22(4), 282-286.

Turner, A. L. \& Quinn, K. F. (1999). Collage students' perceptions of the value of psychological services: A comparison with APA's public education research. Professional Psychology: Research and Practice, 30(4), 368-371.

VandenBos, G. R., DeLeon, P. H. \& Belar, C. D. (1991). How many psychologists are needed? It's too early to know! Professional Psychology: Research and Practice, 22(6), 441-448.

Von Sidow, K. \& Reimer, C. (1998). Attitudes toward psychoterapists, psychologists, psychiatrists and psychoanalysts. A meta-content analysis of 60 studies published between 1948 and 1995. American Journal of Psychotherapy, 52(4), 463-488.

Weaver, T. L., Hughes, H. M., Friedman, P. T., Edwars, T. A. \& Holmes, D. (2006). Pediatric-psychology partnership for abuse prevention. Journal of Clinical Psychology in Medical Settings, 13(1), 13-19.

Webb, A. R. \& Speer, J. R. (1985). The public image of psychologists. American Psychologist, 40(9), 1063. 1064.

Wedding, D. (2008). Innovative methods for making behavioral science relevant to medical education. Journal of Clinical Psychology in Medical Settings, 15(2), 89-91.

Wood, W., Jones, M. \& Benjamin, L. T. (1986). Surveying psychology's public image. American Psychologist, 41(9), 947-953. 
World Health Organization. (2010). Health system country profiles. Retrieved on July 11, 2010, from http:// www.euro.who.int/en/home/projects/observatory/ publications/health-system-profiles-hits/full-listof-hits
Yllá, L. \& Hidalgo, M. S. (2003, July). Diferenciando entre las profesiones de psicólogos y de psiquiatras: un estudio de campo en Vizcaya. Avances en Salud Mental Relacional, 2(2). Retrived on December 1, 2004, from http://bibliopsiquis.com/ asmr/0202/0202del.htm 
